\section{Anaerobic Fermentation of Substrate with High Nitrogen Content}

\author{
N. Gróf ${ }^{*}$ and M. Hutňan \\ Institute of Chemical and Environmental Engineering, \\ Faculty of Chemical and Food Technology, \\ Slovak University of Technology, Radlinského 9, \\ 81237 Bratislava, Slovak Republic
}

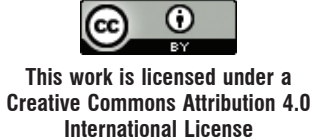

International License

doi: https://doi.org/10.15255/CABEQ.2021.1945

Original scientific paper

Received: March 23, 2021

Accepted: June 30, 2021

This work focuses on anaerobic fermentation of synthetic substrate with high nitrogen content. An anaerobic continuously stirred tank reactor was gradually loaded with synthetic substrate, and the first inhibition was observed on day 110 when the SBP decreased by $20 \%$. Another significant change was observed on day 135, when SBP dropped to $122 \mathrm{~L} \mathrm{~kg}^{-1}$ COD. At the same time, a gas washing bottle with hydrochloric acid was connected to capture ammonia from recirculated biogas. With this arrangement, a slight increase in the SBP production to $150 \mathrm{~L} \mathrm{~kg}^{-1}$ COD was observed. On day 164, the gas washing bottle was changed to two gas washing bottles with fritted discs. After ten days, a significant increase in SBP, to $320 \mathrm{~L} \mathrm{~kg}^{-1} \mathrm{COD}$, was observed, indicating that the system began to overcome inhibition. From these results, it can be concluded that this method is effective in mitigating ammonia inhibition.

Keywords:

absorption, ammonia inhibition, anaerobic digestion, CSTR reactor

\section{Introduction}

Anaerobic fermentation (AD) consists of the decomposition and stabilization of organic substances by microorganisms under anoxic conditions, leading to the formation of biogas and fermentation residue. This microbiological process is widely used, e.g., for the treatment of agricultural waste, municipal and industrial organic waste. ${ }^{1,2}$ These substrates often contain significant amount of nitrogen, which can inhibit microorganisms. ${ }^{3}$ Fermentation of these materials releases ammonia nitrogen predominantly in a less toxic ionized form $\left(\mathrm{NH}_{4}^{+}\right)$at acidic to neutral $\mathrm{pH}$ values. Production of the toxic non-ionized form $\left(\mathrm{NH}_{3}\right)$ increases with the increasing $\mathrm{pH}$. Significant differences in the inhibitory concentrations reported for ammonia in literature can be attributed to differences in substrates, inoculum, and environmental conditions such as temperature and $\mathrm{pH}^{4}{ }^{4,5}$ Hobson $^{6}$ found that TAN concentration of $2500 \mathrm{mg} \mathrm{NH}_{4}-\mathrm{N} \mathrm{L}^{-1}$ resulted particularly in methane production inhibition, while a concentration of $3300 \mathrm{mg} \mathrm{NH}-\mathrm{N} \mathrm{L}^{-1}$ completely inhibited the methanogenesis process. In an adapted process, Angelidaki ${ }^{4}$ state that the tolerance of ammonia nitrogen is up to $3000-4000 \mathrm{mg} \mathrm{NH}_{4}-\mathrm{N} \mathrm{L}^{-1}$. However, Sawayama ${ }^{7}$ and Lauterböck ${ }^{8}$ observed inhibition only when the TAN concentration exceeded $6000 \mathrm{mg} \mathrm{NH}_{4}-\mathrm{N} \mathrm{L}^{-1}$.

${ }^{*}$ Corresponding author: E-mail: nikolas.grof@stuba.sk miroslav.hutnan@stuba.sk
Hansen ${ }^{9}$ studied the effect of different concentrations and temperatures of ammonia on $\mathrm{AD}$ of pig manure. Temperature changes from 37 to $60{ }^{\circ} \mathrm{C}$ and total ammonia concentrations from $5.9 \pm 0.1$ to $6.1 \pm 0.1 \mathrm{~g} \mathrm{~N} \mathrm{~L} \mathrm{~L}^{-1}$ were studied in the experiment. At higher temperatures $\left(55\right.$ and $\left.60{ }^{\circ} \mathrm{C}\right)$ and total ammonia concentrations of $6.0 \pm 0.1 \mathrm{~g} \mathrm{~N} \mathrm{~L} \mathrm{~L}^{-1}$ and $6.1 \pm 0.1 \mathrm{~g} \mathrm{~N} \mathrm{~L}^{-1}$, increased concentrations of free ammonia (1.6 and $2.6 \mathrm{~g} \mathrm{~N} \mathrm{~L}^{-1}$ ) and volatile fatty acids (11.5 and $15.8 \mathrm{~g} \mathrm{Ac} \mathrm{L} \mathrm{L}^{-1}$ ) were observed along with methane yield reduction to 67 and $22 \mathrm{~mL} \mathrm{CH}_{4} \mathrm{~g}^{-1} \mathrm{VS}$, respectively. At mesophilic temperatures $\left(37\right.$ and $\left.45^{\circ} \mathrm{C}\right)$, methane yields (188 and $141 \mathrm{~mL} \mathrm{CH}_{4} \mathrm{~g}^{-1} \mathrm{VS}$ ) were comparatively higher than at thermophilic temperatures, and under reduced free ammonia ( 0.75 and $\left.1.4 \mathrm{~g} \mathrm{~N} \mathrm{~L}^{-1}\right)$ and volatile fatty acids concentrations (4.8 and $\left.5.6 \mathrm{~g} \mathrm{Ac} \mathrm{L}^{-1}\right)$.

Gallert ${ }^{10}$ analyzed the effect of ammonia on methanogenesis under mesophilic and thermophilic conditions. They used peptone $\left(4 \mathrm{~g} \mathrm{~L}^{-1}\right)$ as the substrate in the presence of various amounts of ammonia ranging from 0 to $7000 \mathrm{mg} \mathrm{L}^{-1}$. Under mesophilic conditions, ammonia concentration increased from 0 to $7000 \mathrm{mg} \mathrm{L}^{-1}$ and the biogas production decreased from $400 \mathrm{~mL} \mathrm{~L}^{-1}$ to $40 \mathrm{~mL} \mathrm{~L}^{-1}$. Under thermophilic conditions, biogas production was reduced from $\approx 120 \mathrm{~mL} \mathrm{~L}^{-1}$ to $\approx 40 \mathrm{~mL} \mathrm{~L}^{-1}$. Concentrations of TAN causing $50 \%$ inhibition of methane production under mesophilic and thermophilic conditions were 2900 and $1830 \mathrm{mg} \mathrm{TAN} \mathrm{L}^{-1}$, respectively. 
There are several possible methods to mitigate ammonia inhibition in the AD process, such as e.g., struvite precipitation, ${ }^{11}$ anammox,${ }^{12}$ acclimatization of methanogenic microorganisms, ${ }^{13,14}$ co-digestion, ${ }^{15}$ or ammonia stripping. ${ }^{16-18}$

De la Rubi ${ }^{19}$ investigated the removal of ammonia in sulfuric acid in a recirculated biogas stream at different temperatures $\left(35,55\right.$ and $\left.70{ }^{\circ} \mathrm{C}\right)$ and biogas flow rate $(0.125 ; 0.250$ and 0.375 $\left.\mathrm{L}_{\text {biogas }} \mathrm{L}_{\text {digestate }}{ }^{-1} \mathrm{~min}^{-1}\right)$. It was found that the removal of ammonia from the digestate, where the food waste was processed, was possible with biogas recirculation. An increase in ammonia removal rate $\left(1.8-8.3 \% \mathrm{~d}^{-1}\right)$ was observed at $35{ }^{\circ} \mathrm{C}$ as the flow rate increased from 0.125 to $0.375 \mathrm{~L}_{\text {biogas }} \mathrm{L}_{\text {digestate }}{ }^{-1}$ $\min ^{-1}$. Higher ammonia removal (3.46 and $9.38 \%$ ) was achieved at $55{ }^{\circ} \mathrm{C}$ at flow rate 0.250 and 0.375 $\mathrm{L}_{\text {biogas }} \mathrm{L}_{\text {digestate }}{ }^{-1} \mathrm{~min}^{-1}$. The highest ammonia removal was achieved at $70{ }^{\circ} \mathrm{C}, 18.4$ and $10.4 \% \mathrm{~d}^{-1}$, for 0.250 and $0.375 \mathrm{~L}_{\text {biogas }} \mathrm{L}_{\text {digestate }}{ }^{-1} \mathrm{~min}^{-1}$. However, the authors did not discuss the effects on anaerobic processes and biogas production, only on the efficiency of ammonia removal in recirculated biogas.

Abouelenien ${ }^{16}$ demonstrated that they successfully captured ammonia in sulfuric acid in a recirculated biogas stream during the processing of treated and raw chicken manure. Chicken manure was anaerobically treated for 4 days at $55^{\circ} \mathrm{C}$ with an initial $\mathrm{pH}$ of $8-9$. They were able to capture $82 \%$ of ammonia with this method. They compared the specific methane production of treated chicken manure $\left(195 \mathrm{~mL} \mathrm{~g}^{-1} \mathrm{VS}\right)$ and mixture (1:1) of treated and raw chicken manure $\left(157 \mathrm{~mL} \mathrm{~g}^{-1} \mathrm{VS}\right)$, however, they do not report methane production in the case where no biogas recirculation is involved. They also did not monitor long-term operation after inhibition and subsequent removal of ammonia in the recirculated biogas stream to suppress inhibition.

Jiang $^{20}$ processed the protein-rich substrate. Ammonia was removed from the recirculated biogas by absorption into water. They compared systems R1 and R2, where they recirculated biogas to the biogas headspace at R1 and R2 to the sludge bed. The absorption rate was found to be higher for the R2 system $\left(14.2 \mathrm{mmol} \mathrm{L}^{-1} \mathrm{~d}^{-1}\right)$ than for the R1 system $\left(6.8 \mathrm{mmol} \mathrm{L}^{-1} \mathrm{~d}^{-1}\right)$. These results showed that the R2 system could be processed at a higher organic load $\left(4 \mathrm{~g} \mathrm{VTS} \mathrm{L}^{-1} \mathrm{~d}^{-1}\right)$ than the R1 system ( $3 \mathrm{~g} \mathrm{VTS} \mathrm{L}^{-1} \mathrm{~d}^{-1}$ ), and could capture more ammonia. However, the authors did not achieve inhibition in the work, so they did not clearly demonstrate the suppression of inhibition by removing ammonia in the recirculated biogas.

As the literature suggests, many studies deal with the removal of ammonia from recirculated biogas, but none clearly discuss the effects on biogas production and suppression of ammonia inhibition.
The novelty of this work may be that the removal of ammonia from the recirculated biogas by absorption into hydrochloric acid can effectively remove ammonia from the biogas, it can also affect the production of biogas and suppress ammonia inhibition. Therefore, the aim of this work was to process a synthetic substrate with a high nitrogen content in an anaerobic reactor, and subsequently mitigate ammonia inhibition.

\section{Material and methods}

\section{Kinetic tests}

Kinetic tests were performed according to the standard protocol introduced by Angelidaki. ${ }^{21}$ The tests were performed in borosilicate glass SIMAX with a total volume of $310 \mathrm{~mL}$ in quadruple at three different inoculum to substrate ratios (based on COD) - ISR (ISR2, ISR4, ISR6), and at different concentrations of $\mathrm{NH}_{4}-\mathrm{N}\left(0,2000,6000,8000 \mathrm{mg} \mathrm{L}^{-1}\right)$. The tests were performed under mesophilic conditions $\left(37 \pm 0.5^{\circ} \mathrm{C}\right)$. In total, 52 bottles were used for the kinetic tests. To each bottle, $200 \mathrm{~g}$ of inoculum (anaerobically stabilized sludge) was dosed with total dry matter of $16.9 \mathrm{~g} \mathrm{~kg}^{-1}$ and with volatile solids of $10.5 \mathrm{~g} \mathrm{~kg}^{-1}$, the appropriate amount of substrate, according to individual ISR ratios, and ammonium chloride were added to increase the nitrogen concentration. A synthetic substrate (same as for longterm reactor operation), consisting of non-fat dry milk powder and peptone, was used in the tests. In the substrate itself, the concentration of total nitrogen was already $7.6 \mathrm{~g} \mathrm{~L}^{-1}$ (Tab. 1), which means that at sign $0 \mathrm{mg} \mathrm{L}^{-1} \mathrm{NH}_{4}-\mathrm{N}$ there was a certain amount of nitrogen in the system. $\mathrm{NH}_{4}-\mathrm{N}$ was added in the tests because in a batch test, nitrogen present in the substrate may not cause inhibition due to the dilution.

Biogas production was monitored at regular intervals in all tests. Biogas production of each sample was determined volumetrically, ${ }^{22}$ providing constant atmospheric pressure conditions. The biogas volume was measured by replacing water in the measurement device. For each measurement time, a needle was inserted into the rubber stopper of the sample bottle. This way, the headspace of each sample was connected to the top of a $50-\mathrm{mL}$ glass burette filled with water. The opening at the bottom of the burette was linked with a rubber tube to a glass cylindrical flask containing water as well. The biogas produced flowed from the headspace of each bottle up into the burette and replaced the water that flowed from the burette to the cylindrical flask. The volume of biogas was taken as the volume of released water, readable from a graduated scale (in $\mathrm{mL}$ ). Each bottle was stirred manually before the 
gas volume measurement, to favor the release of biogas into the headspace. Kinetic tests were evaluated using first order kinetic reactions.

\section{First order kinetic model}

First order kinetic model is the simplest model used to describe the exponential biogas production rate of the $\mathrm{AD}$ process, assuming that hydrolysis is the rate-limiting step, according to the equation: ${ }^{23}$

where:

$$
G(t)=G_{0}\left(1-e^{-k \cdot t}\right)
$$

$G(t)$ - cumulative biogas (or methane) yield at digestion time $t$ ( $\left.\mathrm{mL} \mathrm{g}^{-1} \mathrm{COD}\right)$,

$G_{0}$ - biogas (or methane) potential of substrate $\left(\mathrm{mL} \mathrm{g}^{-1} \mathrm{COD}\right)$, also called ultimate biogas or methane potential

$k$ - biogas (or methane) production rate constant or first order disintegration rate constant $\left(\mathrm{L} \mathrm{d}^{-1}\right)$

$t$ - digestion time (d).

A nonlinear least-square regression analysis was performed using the solver tool in MATLAB 2019 to fit the kinetic equation of the first order to the average cumulative specific biogas production (SBP) curves. This method searches for the main kinetic parameters for model with the primary aim of minimizing the sum of the squares of the differences between the predicted and the measured values.

\section{Long-term operation of CSTR reactor}

The experiment was performed in a CSTR reactor (Fig. 1) made of stainless steel by ASIO - SR s.r.o., with an operating volume of $6.5 \mathrm{~L}$. The diameter and height of the reactor were $20 \mathrm{~cm}$ and 25 $\mathrm{cm}$, respectively. At the top of the reactor was a feeding hole, a thermometer for monitoring and regulating the temperature, and a $\mathrm{pH}$ probe (GP HU014MP, Greisinger) for continuous monitoring of the $\mathrm{pH}$ in the reactor. Data were recorded at five-minute intervals in the AMiT control program with unlimited archiving time. Stirring of the reactor was ensured by a paddle stirrer with adjustable rpm (Heidolph RZP 2020). The rpm was maintained at a frequency of 30. Anaerobically stabilized sludge from the wastewater treatment plant (WWTP) Devínska Nová Ves with an initial total solid (TS) concentration of $25.86 \mathrm{~g} \mathrm{~kg}^{-1}$ and volatile solid (VS) concentration of $14.98 \mathrm{~g} \mathrm{~kg}^{-1}(57.8 \%)$ was used as inoculum. The reactor was operated under mesophilic

Table 1 - Basic characteristics of substrate

\begin{tabular}{ccc|c|c}
\hline & $\mathrm{COD}\left(\mathrm{g} \mathrm{L}^{-1}\right)$ & $\mathrm{TS}\left(\mathrm{g} \mathrm{kg}^{-1}\right)$ & $\mathrm{VS}\left(\mathrm{g} \mathrm{kg}^{-1}\right)$ & $\mathrm{N}_{\text {TOT }}\left(\mathrm{g} \mathrm{L}^{-1}\right)$ \\
\hline Substrate & 96 & 66.4 & 59.5 & 7.6 \\
\hline
\end{tabular}

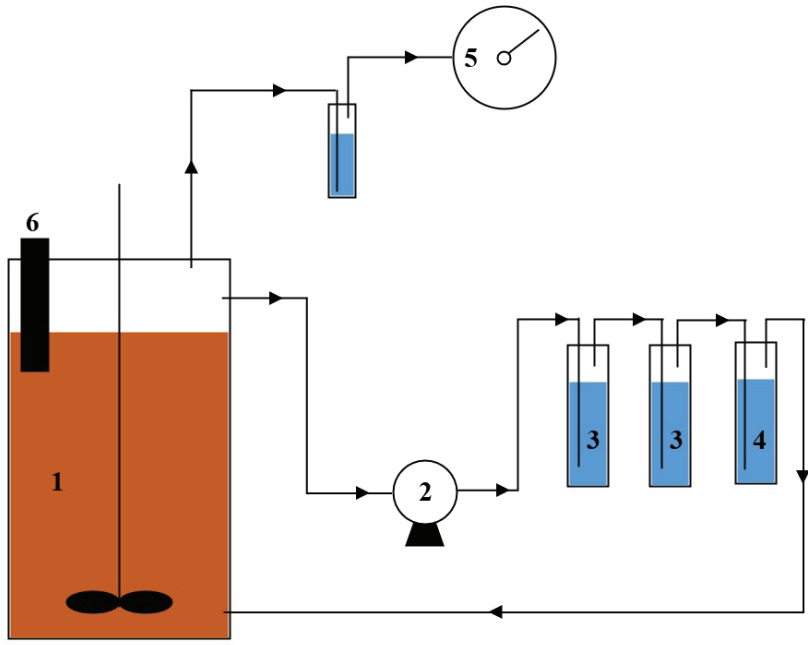

Fig. 1 - Scheme of CSTR reactor with external ammonia removal: 1 -CSTR reactor, 2 - peristaltic pump, 3 - gas washing bottle with $10 \% \mathrm{HCl}$ solution, 4 - washing bottle with distilled water, 5 -drum gas meter, 6 -feeding hole

conditions $\left(37 \pm 0.5{ }^{\circ} \mathrm{C}\right)$. Reactor start-up started at an organic loading rate (OLR) of $0.25 \mathrm{~g} \mathrm{COD} \mathrm{L}^{-1} \mathrm{~d}^{-1}$. After reaching the OLR of $2 \mathrm{~g} \mathrm{COD} \mathrm{L}^{-1} \mathrm{~d}^{-1}$ and achieving ammonia inhibition, a recirculation device for biogas purification was installed. A distribution element (on day 135) was installed at the outlet to pass a part of the biogas through a gas washing bottle with hydrochloric acid $(\mathrm{HCl})$ and distilled water, and the excess biogas was discharged through a water seal and a drum gas meter. Biogas was pumped from the reactor headspace to an external gas washing bottle using a peristaltic pump (Heidolph Pumpdrive 5001), with a flow rate of $5 \mathrm{~L} \mathrm{~d}^{-1}$, and from day 150 , the flow rate was increased to $15 \mathrm{~L} \mathrm{~d}^{-1}$. The change occurred on day 164 , when the gas washing bottle was replaced with two gas washing bottles with fritted discs to ensure an increase in surface area for the phase transfer of ammonia from biogas to hydrochloric acid. Subsequently, the biogas was returned through the lower side valve directly into the sludge bed. Biogas recirculation ensured stripping of ammonia from the sludge bed. Synthetic substrate consisting of non-fat dry milk powder and peptone in the ratio of $3: 1$ based on chemical oxygen demand (COD) was used as the substrate. Basic characteristics of the substrate are shown in Table 1.

During long-term operation of the laboratory model, parameters such as $\mathrm{pH}$ (Hach HQ11d), chemical oxygen demand (COD), total ammonia nitrogen (TAN), total nitrogen $\left(\mathrm{N}_{\mathrm{TOT}}\right)$, and volatile fatty acids (VFA) were monitored according to APHA, AWWA, WEF (2017). ${ }^{21}$ Analyzes were performed from filtered sludge water taken as excess sludge. The concentration of free ammonia nitrogen (FAN) was calculated according to the following equation: ${ }^{24}$ 


$$
\mathrm{FAN}=\mathrm{TAN} \cdot\left(1+\frac{10^{-\mathrm{pH}}}{10^{-\left(0.09018+\frac{2729.92}{T(\mathrm{~K})}\right)}}\right)^{-1}
$$

Where:

FAN - free ammonia nitrogen concentration $\left(\mathrm{mg} \mathrm{L}^{-1}\right)$ TAN - total ammonia nitrogen concentration $\left(\mathrm{mg} \mathrm{L}^{-1}\right)$ $T$ - temperature $(\mathrm{K})$.

In addition, the amount of biogas produced (at laboratory temperature) was measured using a drum gas meter (type AMS Spectrum TCM 143/10 4726), and biogas composition was measured using a portable gas analyzer GA 2000 Plus (Geotechnical Instruments, UK). This analyzer is able to measure the content of the following compound: $\mathrm{CH}_{4}, \mathrm{CO}_{2}$, $\mathrm{O}_{2}, \mathrm{H}_{2}$ and $\mathrm{H}_{2} \mathrm{~S}$. $\mathrm{CH}_{4}$ and $\mathrm{CO}_{2}$ contents were measured by infrared cell, while $\mathrm{O}_{2}, \mathrm{H}_{2}$ and $\mathrm{H}_{2} \mathrm{~S}$ contents by electrochemical cell. The biogas for determination of the composition was collected in the sampling bag.

\section{Results and discussion}

\section{Kinetic tests}

The $\mathrm{pH}$ values measured at the beginning of the test ranged from 6.83 to 7.64 . At the end of the test, the lowest $\mathrm{pH}$ was 5.42 and the highest was 7.15. In Fig. 2, ISR2 2000 represents a test at the ratio of $\mathrm{ISR}=2$, and the dose of ammonia nitrogen of $2000 \mathrm{mg} \mathrm{L}^{-1}$. Lower $\mathrm{pH}$ values from 5.42 to 6.16 were recorded at all ISR ratios where the concentration of ammonia nitrogen was increased, suggesting inhibition of anaerobic processes due to the high ammonia concentration. The decrease in $\mathrm{pH}$ was due to successive phenomena as the high concentration of ammonia inhibits methanogenesis so that VFA does not decompose in the system, but the first phases of anaerobic decomposition continue, so VFA begins to accumulate in the system, which in turn leads to lower $\mathrm{pH}$. At the other ratios, namely ISR2, 4 and 6 , the $\mathrm{pH}$ values were in the neutral range after the end of the test (6.83-7.15).

Based on the measured biogas production at individual ISR ratios, curves of specific cumulative biogas production (SBP) were constructed, where SBP was expressed as the volume of biogas produced from the mass of COD in the sample. Fig. 2 shows SBP for all three ISR ratios used in the experiment. This biogas production is only indicative as it is influenced by the conditions of a disposable kinetic test. The concentration of ammonia in the substrate was sufficient to achieve inhibition, but the substrate was diluted in single tests and the in-
Table 2 -Maximum volumes of biogas produced at different ISR ratios and different ammonia nitrogen concentrations, and theoretical biogas production

\begin{tabular}{c|c|c|c}
\hline \multirow{2}{*}{$\begin{array}{c}\mathrm{NH}_{4}-\mathrm{N} \\
\left(\mathrm{mg} \mathrm{L}^{-1}\right)\end{array}$} & \multicolumn{3}{|c}{ Biogas production $(\mathrm{mL})$} \\
\cline { 2 - 4 } & ISR=2 & ISR=4 & ISR=6 \\
\hline 0 & 401 & 545 & 656 \\
2000 & 111 & 140 & 236 \\
6000 & 26 & 59 & 70 \\
8000 & 33 & 34 & 37 \\
$\begin{array}{c}\text { Theoretical biogas } \\
\text { production }\end{array}$ & 1357 & 828 & 552 \\
\hline
\end{tabular}

hibitory effect may not have occurred, therefore these doses of ammonia nitrogen were used in the tests.

Table 2 shows the maximum volumes of biogas produced at different ISR ratios and different ammonia nitrogen concentrations, and theoretical biogas production considering the theoretical specific production of methane of $0.35 \mathrm{~m}^{3} \mathrm{~kg}^{-1} \mathrm{COD}$ and the concentration of methane in the produced biogas of $50 \%$.

A comparison of theoretical and real biogas production showed approximately $75 \%$ inhibition at $\mathrm{ISR}=2$, and almost no inhibition at ISR $=6$. From the course of the experimental curves, it can be seen that the specific biogas production decreased with the increasing concentration of ammonia nitrogen, already at a dose of $2000 \mathrm{mg} \mathrm{L}^{-1}$ of ammonia nitrogen, $93 \%$ inhibition occurred. With further increase in ammonia nitrogen to $6000 \mathrm{mg} \mathrm{L}^{-1}$ and $8000 \mathrm{mg} \mathrm{L}^{-1}$, inhibition of approximately $100 \%$ could be observed.

Table 3 shows kinetic parameters (experimental and calculated) for the first order kinetics. In Fig. 2, the courses of experimental values and calculated values of biogas production according to first order kinetics at different ratios of ISR and ammonia nitrogen concentration are presented.

Such biogas production is only indicative as it is influenced by the conditions of a single kinetic test. Actual biogas production may be higher because the anaerobic biomass adapts to the substrate during continuous processing of the substrate in an anaerobic reactor. Actual production may also be lower as the continuous processing leads to gradual concentration of inhibitors, which may not be apparent when diluted in a single test.

\section{Long-term operation of anaerobic reactor}

Start-up of the anaerobic reactor took 97 days, when OLR of $2 \mathrm{~g} \mathrm{COD} \mathrm{L}^{-1} \mathrm{~d}^{-1}$ was achieved. The average specific biogas production was $536 \mathrm{~L} \mathrm{~kg}^{-1} \mathrm{COD}$ 
ISR 2

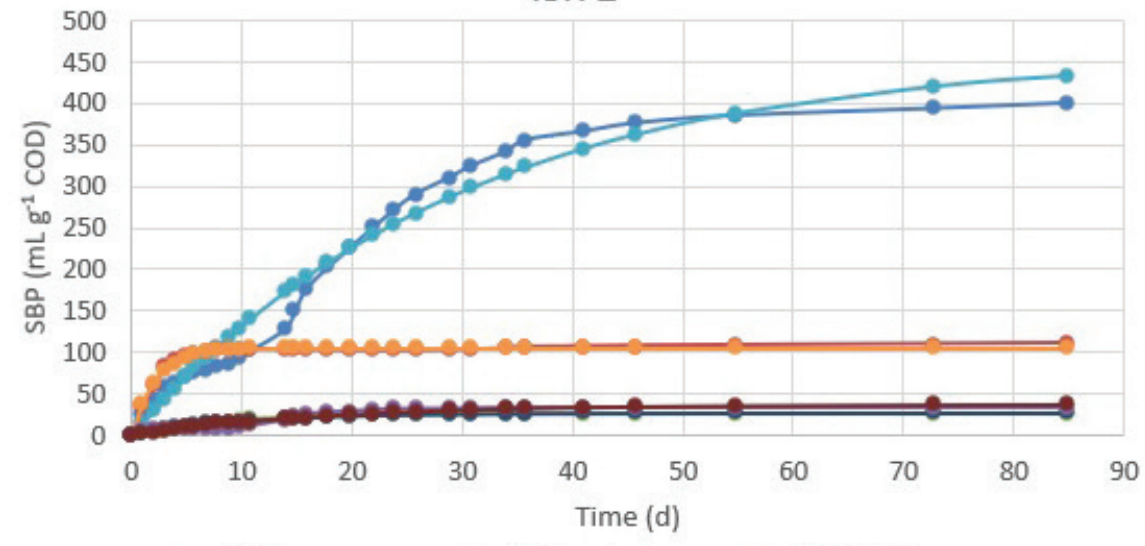

$$
\begin{array}{ll}
\rightarrow \text { ISR 2 } & \rightarrow \text { ISR 2 model } \\
\rightarrow \text { ISR 2_2000 model } & \rightarrow \text {-ISR 2_6000 } \\
\rightarrow \text { ISR 2_8000 2_2000 } & \rightarrow \text { ISR 2_6000 model }
\end{array}
$$

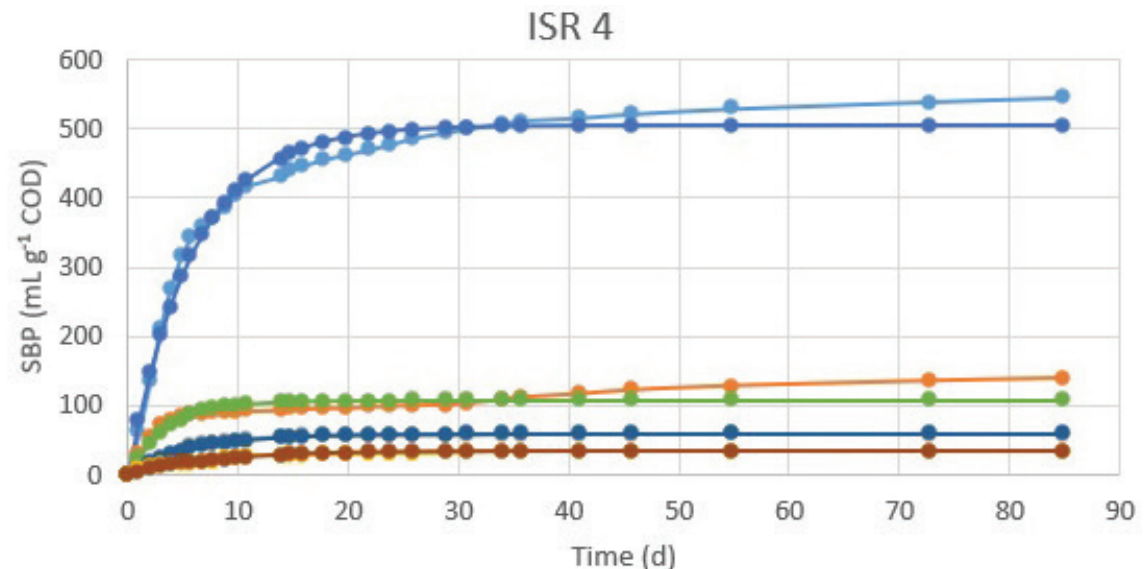

$$
\begin{array}{ll}
\rightarrow \text { ISR 4 } & \rightarrow \text { ISR 4 model } \\
\rightarrow \text {-ISR 4_2000 model } & \rightarrow-\text { ISR 4_6000 ISR 4_2000 } \\
\longrightarrow \text { ISR 4_8000 } & \rightarrow-\text { ISR 4_8000 model }
\end{array}
$$

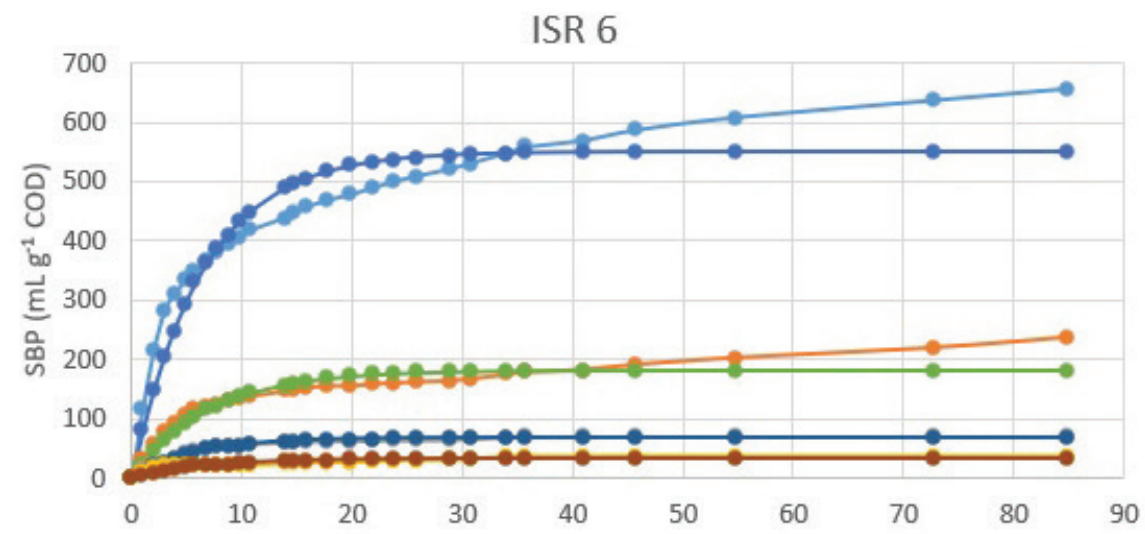

Time (d)

$$
\begin{aligned}
& \rightarrow \text { ISR 6 } \rightarrow \text { ISR 6 model } \rightarrow \text { ISR 6_2000 } \\
& \rightarrow-\text { ISR 6_2000 model } \rightarrow \text {-ISR 6_6000 } \rightarrow \text { ISR 6_6000 model } \\
& \longrightarrow \text {-ISR 6_8000 } \rightarrow \text { ISR 6_8000 model }
\end{aligned}
$$

Fig. 2 - Experimental values and calculated values (model) of biogas production according to first order kinetics at different ISR ratios and ammonia nitrogen concentrations 
Table 3 - Experimental and calculated kinetic parameters for first order kinetics

\begin{tabular}{l|c|c|c|c|c}
\hline & $\begin{array}{c}G_{0} \\
{\left[\mathrm{~mL} \mathrm{~g}^{-1}\right.} \\
\mathrm{COD}]\end{array}$ & $\begin{array}{c}k \\
{\left[\mathrm{~L} \mathrm{~d}^{-1}\right]}\end{array}$ & $\begin{array}{c}\text { SBP } \\
(\mathrm{exp} .) \\
{\left[\mathrm{mL} \mathrm{g}^{-1}\right.} \\
\mathrm{COD}]\end{array}$ & $\begin{array}{c}\text { SBP } \\
(\mathrm{model}) \\
{\left[\mathrm{mL} \mathrm{g}^{-1}\right.} \\
\mathrm{COD}]\end{array}$ & $R^{2}$ \\
\hline Blank & 10.69 & 0.0369 & 10 & 10 & 0.9959 \\
ISR 2 & 458.30 & 0.0342 & 401 & 433 & 0.9853 \\
ISR 2_2000 & 104.75 & 0.4750 & 111 & 105 & 0.9939 \\
ISR 2_6000 & 27.29 & 0.1055 & 26 & 27 & 0.9924 \\
ISR 2_8000 & 36.77 & 0.0583 & 33 & 37 & 0.9601 \\
ISR 4 & 504.22 & 0.1728 & 545 & 504 & 0.9899 \\
ISR 4_2000 & 108.30 & 0.2824 & 140 & 108 & 0.9065 \\
ISR 4_6000 & 59.66 & 0.1797 & 59 & 60 & 0.9951 \\
ISR 4_8000 & 34.04 & 0.1371 & 34 & 34 & 0.9850 \\
ISR 6 & 549.72 & 0.1581 & 656 & 550 & 0.9561 \\
ISR 6_2000 & 182.47 & 0.1444 & 236 & 182 & 0.9488 \\
ISR 6_6000 & 67.29 & 0.1821 & 70 & 67 & 0.9940 \\
ISR 6_8000 & 32.87 & 0.1558 & 37 & 33 & 0.9009 \\
\hline
\end{tabular}

with methane content of approximately $56 \%$. Fig. 3 shows the specific biogas production during the experiment.

Fig. 4 describes the course of nitrogen compounds concentration in the reactor. During the start-up, an increase in the concentration of ammo- nia and total nitrogen can be seen. This phenomenon can be explained by an excess of nutrients in the substrate. The concentration of free ammonia nitrogen (FAN) was at the level of $60 \mathrm{mg} \mathrm{L}^{-1}$. A significant increase occurred on day 63 when the FAN concentration doubled, probably due to an increase in $\mathrm{pH}$ to 7.6 (Fig. 5).

At day 110 of reactor operation, a decrease $(20 \%)$ in biogas production was recorded for the first time, which can be seen in Fig. 3. This decrease was caused by an increase in the TAN concentration to $4733 \mathrm{mg} \mathrm{L}^{-1}$ and FAN concentration to $402 \mathrm{mg} \mathrm{L}^{-1}$. Also, from this day, continuous increase in the concentration of COD to $12380 \mathrm{mg} \mathrm{L}^{-1}$ and VFA to $7480 \mathrm{mg} \mathrm{L}^{-1}$ was observed (Fig. 5). Similar results were achieved by Sung. ${ }^{25}$ At a TAN concentration of $4.92 \mathrm{~g} \mathrm{~L}^{-1}$, they observed a $39 \%$ decrease in biogas production and an accumulation of VFA in the reactor.

At day 135 of reactor operation, the specific biogas production decreased to $122 \mathrm{~L} \mathrm{~kg}^{-1}$ COD (Fig. 3), representing an approximately $77 \%$ decrease in biogas production. In kinetic tests, inhibition was already observed at $2000 \mathrm{mg} \mathrm{L}^{-1} \mathrm{NH}_{4}-\mathrm{N}$, but in the reactor operation, it was achieved only at a TAN concentration of about $4000 \mathrm{mg} \mathrm{L}^{-1}$. This may be due to the acclimatization of anaerobic biomass during long-term operation. The quality of biogas also deteriorated with the methane content falling to $47.3 \%$. At the same time, external removal of ammonia from the system was started. The

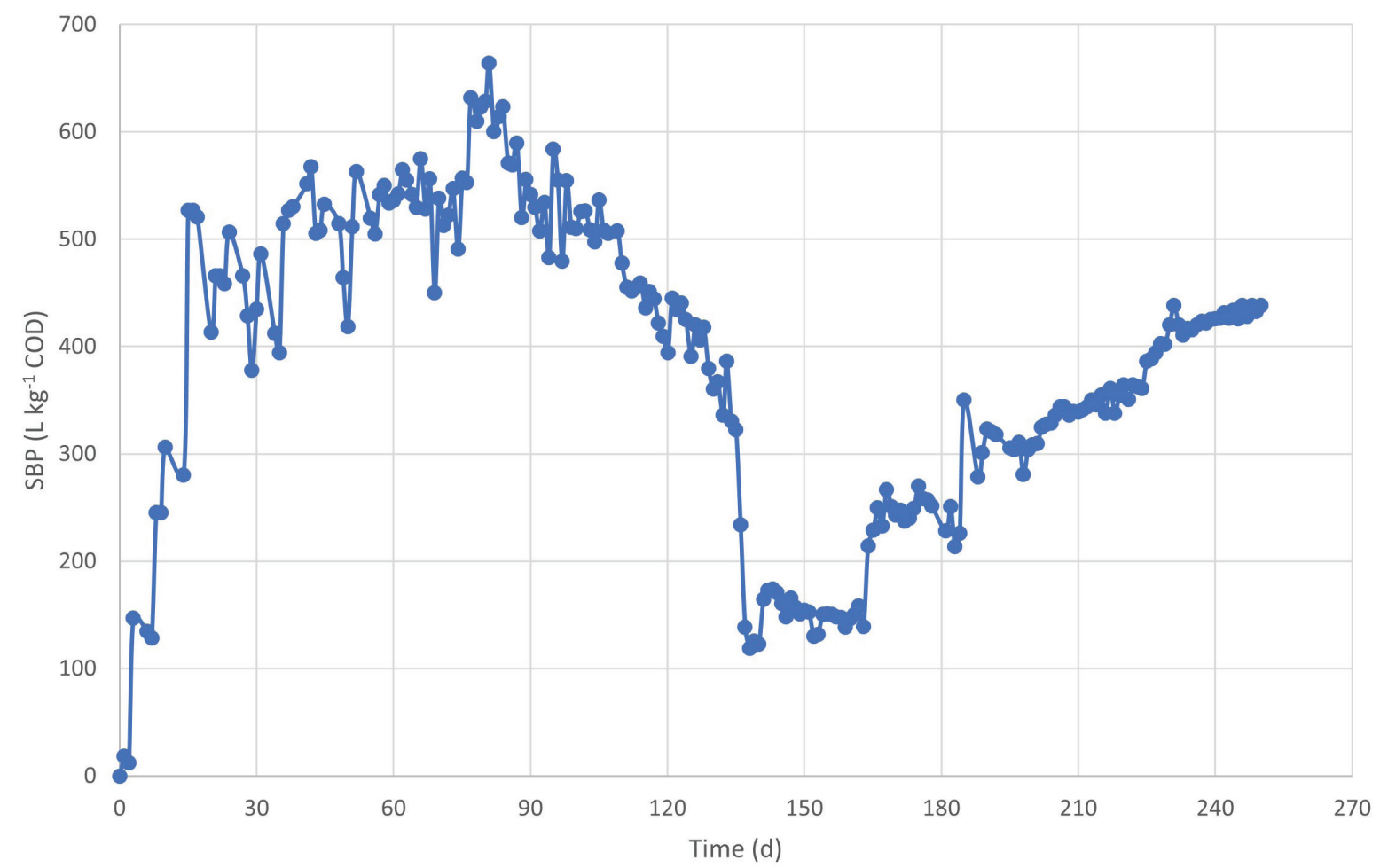

Fig. 3 - Specific biogas production (SBP) 


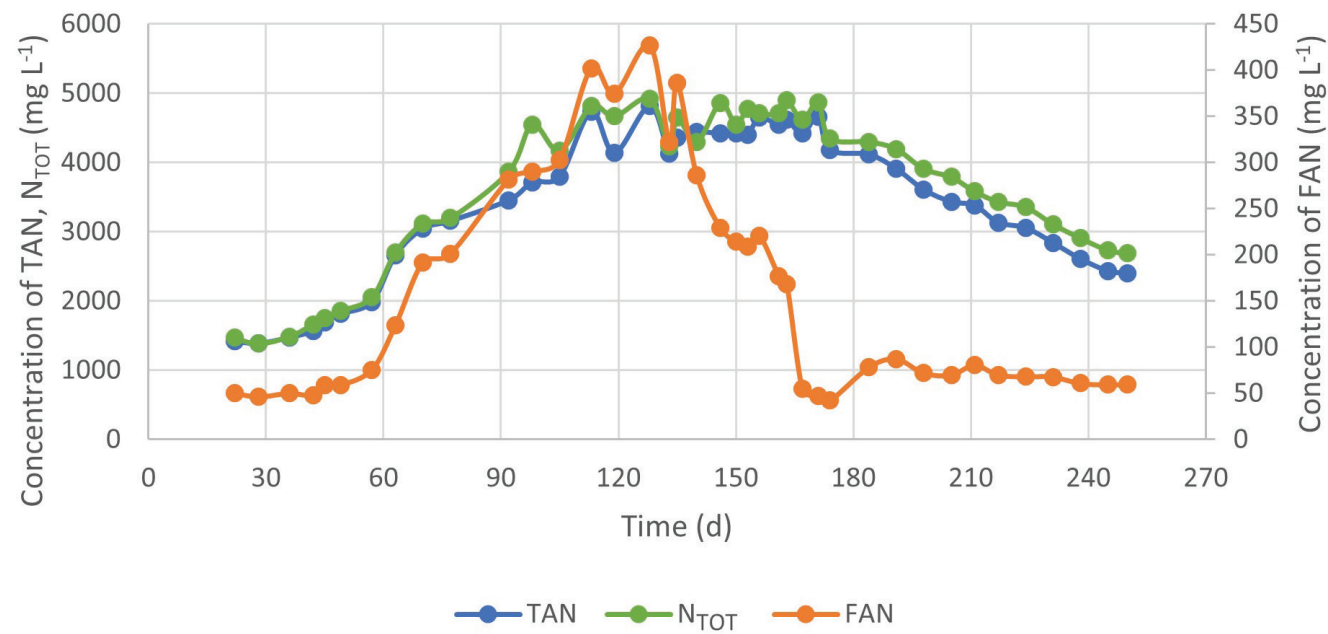

Fig. 4 - Concentration of total nitrogen $\left(N_{\text {TOT }}\right)$, total ammonia nitrogen (TAN), and free ammonia nitrogen (FAN)

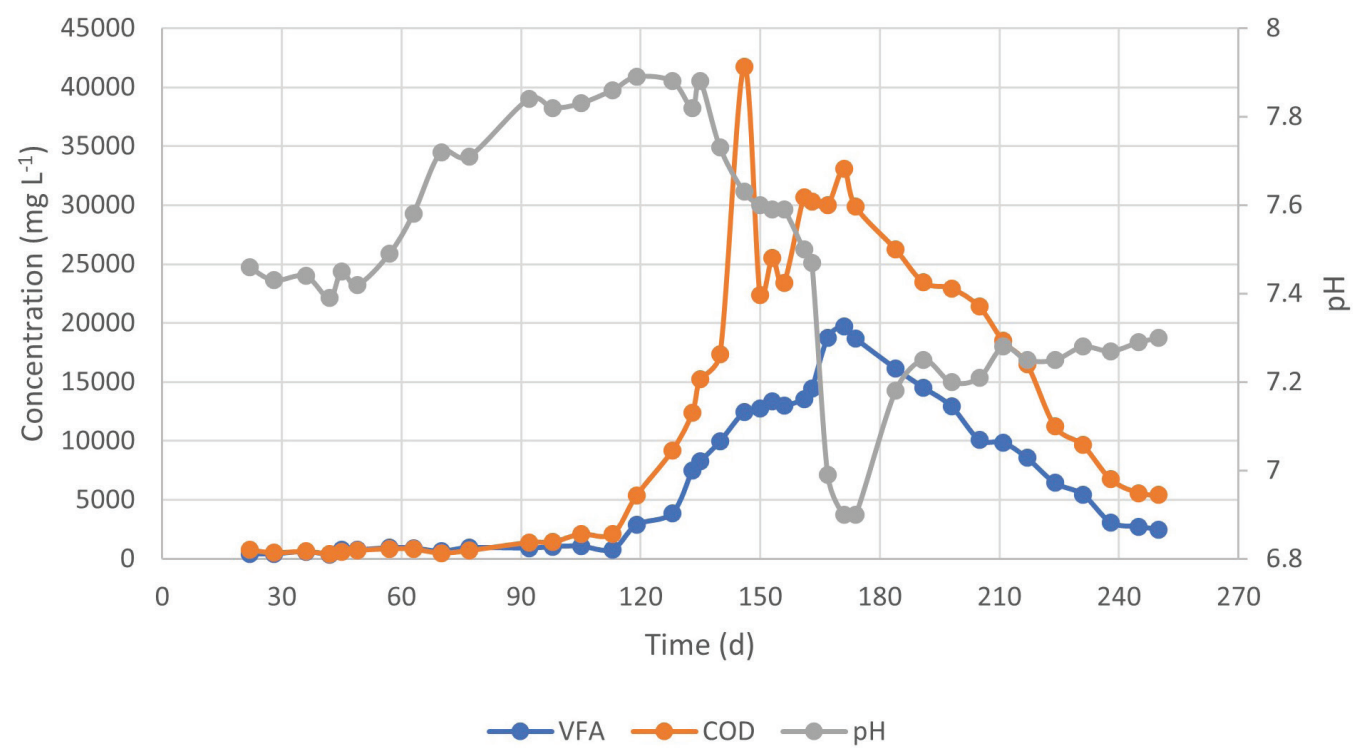

Fig. 5 - Volatile fatty acids (VFA) and chemical oxygen demand (COD) concentration and pH profile

flow of recirculated biogas was approximately $5 \mathrm{~L} \mathrm{~d}^{-1}$, and it was firstly passed through a $10 \% \mathrm{HCl}$ solution, and then through distilled water, and returned to the bottom of the reactor. As may be seen in Fig. 4 removal of ammonia from the system provided a slight decrease in FAN concentration to $229 \mathrm{mg} \mathrm{L}^{-1}$. The same trend could be observed for $\mathrm{pH}$ changes (Fig. 5). However, this process design was ineffective as the concentration of COD and VFA continued to increase; COD concentration increased to $41750 \mathrm{mg} \mathrm{L}^{-1}$ and VFA concentration to $12460 \mathrm{mg} \mathrm{L}^{-1}$. Ammonia removal also had a positive effect on the specific biogas production, which may be seen in Fig. 3.

At day 150, the recirculated biogas flow increased to $15 \mathrm{~L} \mathrm{~d}^{-1}$; which, however, had no significant effect on the specific biogas production (Fig. 3 ) or on the TAN or FAN output parameter (Fig. 4), but the COD concentration dropped very signifi- cantly by about $50 \%$ (Fig. 5). A slight increase could still be observed in the concentration of VFA.

At day 164, the gas washing bottle was changed with two gas washing bottles with fritted discs (extra coarse frit with pores size of 100-160 mm) in a row to remove ammonia from the recirculated biogas. This change increased the specific biogas production to $214 \mathrm{~L} \mathrm{~kg}^{-1}$ COD (Fig. 3). Favorable effect on output parameters was also observed. In Fig. 5 , a sudden decrease in $\mathrm{pH}$ caused by the accumulation of VFA in the reactor may be seen. The decrease in $\mathrm{pH}$ in the reactor also ensured a decrease in FAN, which may be seen in Fig. 4.

At day 174 , the system began to overcome the inhibition, which could be observed in the increase in specific biogas production (Fig. 3), and methane content increase in biogas back to $55.6 \%$. Also, Figs. 4 and 5 show that the concentration of the monitored parameters decreased. 
The ammonia removal efficiency in $\mathrm{HCl}$ was monitored between 184 and 217 days of reactor operation. During this period, the $\mathrm{HCl}$ in gas washing bottles changed 4 times (every 8 days). The average concentration of $\mathrm{NH}_{4}-\mathrm{N}$ in the gas washing bottles after 8 days was $3620 \mathrm{mg} \mathrm{L}^{-1}$, which represents an ammonia absorption rate $32.3 \mathrm{mmol} \mathrm{L}^{-1} \mathrm{~d}^{-1}$. This is approximately $4-5$ times higher than reported by $\operatorname{Sun}^{26}$ (6.3-7.8 mmol L $\left.{ }^{-1} \mathrm{~d}^{-1}\right)$. However, they captured ammonia from biogas in clean water. With a total volume of $\mathrm{HCl}$ solution in the gas washing bottles of $225 \mathrm{~mL}$, the absolute amount of removed $\mathrm{NH}_{4}-\mathrm{N}$ was $814.5 \mathrm{mg}$. After four changes of the contents of the gas washing bottles, the amount of removed $\mathrm{NH}_{4}-\mathrm{N}$ was $3.26 \mathrm{~g}$. At that time, the $\mathrm{NH}-\mathrm{N}$ concentration decreased from 4117 to $3133.5 \mathrm{mg} \mathrm{L}^{-1}$, which was $6.39 \mathrm{~g}$ of $\mathrm{NH}_{4}-\mathrm{N}$ at a reactor volume of $6.5 \mathrm{~L}$. We can therefore conclude that the removed amount of $\mathrm{NH}_{4}-\mathrm{N}$ was approximately $51 \%$ of the decrease in $\mathrm{NH}_{4}-\mathrm{N}$ in the reactor. An overall nitrogen balance could not be performed because the system was in an unsteady state of ammonia inhibition reduction. The $\mathrm{pH}$ remained almost unchanged after 8 days and was less than 1 .

\section{Conclusion}

Treatment of a synthetic substrate with high nitrogen content in an anaerobic reactor leads to inhibition of anaerobic microorganisms. Kinetic tests showed that the substrate itself could cause inhibition of the process due to low $\mathrm{C}: \mathrm{N}$ ratio of 13 . Therefore, the C:N ratio has to be adjusted, or the reactor can be operated at lower OLR or with long hydraulic retention time. The first inhibition was monitored during long-term operation of the reactor at day 110. From this day, biogas production gradually decreased, and reached $77 \%$ inhibition on day 135. On the same day, the removal of ammonia from the recirculated biogas began. Removal of ammonia by means of a gas washing bottle was not as effective as that using gas washing bottles with fritted discs connected in series. This is because relatively large bubbles are formed in the gas washing bottle compared to the gas washing bottle with fritted discs, where the bubbles are much smaller, and thus, the surface and contact with the absorbent is much larger.

According to the currently measured values, it can be concluded that the capture of ammonia in hydrochloric acid is an effective method for mitigating the inhibitory effect of ammonia in the anaerobic reactor.

\section{ACKNOWLEDGEMENT}

This work was supported by the Slovak Grant Agency for Science VEGA (grant 1/0772/16).

\section{References}

1. Jha, P., Schmidt, S., Reappraisal of chemical interference in anaerobic digestion processes, Renew. Sustain. Energy Rev. 75 (2017) 954.

doi: https://doi.org/10.1016/j.rser.2016.11.076

2. Li, Y., Park, S. Y., Zhu, J., Solid-state anaerobic digestion for methane production from organic waste, Renew. Sustain. Energy Rev. 15 (2011) 821. doi: https://doi.org/10.1016/j.rser.2010.07.042

3. Koster, I. W., Lettinga, G., The influence of ammonium-nitrogen on the specific activity of pelletized methanogenic sludge, Agric. Wastes 9 (1984) 205. doi: https://doi.org/10.1016/0141-4607(84)90080-5

4. Angelidaki, I., Ahring, B. K., Anaerobic thermophilic digestion of manure at different ammonia loads: Effect of temperature, Water Res. 28 (1994) 727. doi: https://doi.org/10.1016/0043-1354(94)90153-8

5. de Baere, L. A., Devocht, M., Van Assche, P., Verstraete, W., Influence of high $\mathrm{NaCl}$ and $\mathrm{NH}_{4} \mathrm{Cl}$ salt levels on methanogenic associations, Water Res. 18 (1984) 543. doi: https://doi.org/10.1016/0043-1354(84)90201-X

6. Hobson, P. N., Shaw, B. G., Inhibition of methane production by Methanobacterium formicicum, Water Res. 10 (1976) 849.

doi: https://doi.org/10.1016/0043-1354(76)90018-X

7. Sawayama, S., Tada, C., Tsukahara, K., Yagishita, T., Effect of ammonium addition on methanogenic community in a fluidized bed anaerobic digestion, J. Biosci. Bioeng. 97 (2004) 65. doi: https://doi.org/10.1016/S1389-1723(04)70167-X

8. Lauterböck, B., Ortner, M., Haider, R., Fuchs, W., Counteracting ammonia inhibition in anaerobic digestion by removal with a hollow fiber membrane contactor, Water Res. 46 (2012) 4861. doi: https://doi.org/10.1016/j.watres.2012.05.022

9. Hansen, K. H., Angelidaki, I., Ahring, B. K., Anaerobic digestion of swine manure: Inhibition by ammonia, Water Res. 32 (1998) 5. doi: https://doi.org/10.1016/S0043-1354(97)00201-7 
10. Gallert, C., Bauer, S., Winter, J., Effect of ammonia on the anaerobic degradation of protein by a mesophilic and thermophilic biowaste population, Appl. Microbiol. Biotechnol. 50 (1998) 495.

doi: https://doi.org/10.1007/s002530051326

11. Uludag-Demirer, S., Demirer, G. N., Chen, S., Ammonia removal from anaerobically digested dairy manure by struvite precipitation, Process Biochem. 40 (2005) 3667. doi: https://doi.org/10.1016/j.procbio.2005.02.028

12. Dong, X., Tollner, E. W., Evaluation of Anammox and denitrification during anaerobic digestion of poultry manure, Bioresour. Technol. 86 (2003) 139. doi: https://doi.org/10.1016/S0960-8524(02)00154-2

13. Abouelenien, F., Nakashimada, Y., Nishio, N., Dry mesophilic fermentation of chicken manure for production of methane by repeated batch culture, J. Biosci. Bioeng. 107 (2009) 293. doi: https://doi.org/10.1016/j.jbiosc.2008.10.009

14. Calli, B., Mertoglu, B., Inanc, B., Yenigun, O., Methanogenic diversity in anaerobic bioreactors under extremely high ammonia levels, Enzyme Microb. Technol. 37 (2005) 448. doi: https://doi.org/10.1016/j.enzmictec.2005.03.013

15. Pedizzi, C., Lema, J. M., Carballa, M., Enhancing thermophilic co-digestion of nitrogen-rich substrates by air sidestream stripping, Bioresour. Technol. 241 (2017) 397. doi: https://doi.org/10.1016/j.biortech.2017.05.113

16. Abouelenien, F., Fujiwara, W., Namba, Y., Kosseva, M., Nishio, N., Nakashimada Y., Improved methane fermentation of chicken manure via ammonia removal by biogas recycle, Bioresour. Technol. 101 (2010) 6368. doi: https://doi.org/10.1016/j.biortech.2010.03.071

17. Yabu, H., Sakai, C., Fujiwara, T., Nishio, N., Nakashimada, $Y$., Thermophilic two-stage dry anaerobic digestion of model garbage with ammonia stripping, J. Biosci. Bioeng. 111 (2011) 312. doi: https://doi.org/10.1016/j.jbiosc.2010.10.011

18. Zhang, L., Jahng, D., Enhanced anaerobic digestion of piggery wastewater by ammonia stripping: Effects of alkali types, J. Hazard. Mater. 182 (2010) 536. doi: https://doi.org/10.1016/j.jhazmat.2010.06.065
19. De la Rubia, M. Á., Walker, M., Heaven, S., Banks, C. J., Borja, R., Preliminary trials of in situ ammonia stripping from source segregated domestic food waste digestate using biogas: Effect of temperature and flow rate, Bioresour. Technol. 101 (2010) 9486. doi: https://doi.org/10.1016/j.biortech.2010.07.096

20. Jiang, X., Hayashi, J., Sun, Z. Y., Yang, L., Tang, Y. Q., Oshibe, H., Osaka, N., Kida, K., Improving biogas production from protein-rich distillery wastewater by decreasing ammonia inhibition, Process Biochem. 48 (2013) 1778. doi: https://doi.org/10.1016/j.procbio.2013.08.014

21. Angelidaki, I., Alves, M., Bolzonella, D., Borzacconi, L., Campos, J. L., Guwy, A. J., Kalyuzhnyi, S., Jenicek, P., van Lier, J. B., Defining the biomethane potential (BMP) of solid organic wastes and energy crops: A proposed protocol for batch assays, Water Sci. Technol. 59 (2009) 927. doi: https://doi.org/10.2166/wst.2009.040

22. Filer, J., Ding, H. H., Chang, S., Biochemical methane potential (BMP) assay method for anaerobic digestion research, Water 11 (2019) 921. doi: https://doi.org/10.3390/w11050921

23. Kafle, G. K., Chen, L., Comparison on batch anaerobic digestion of five different livestock manures and prediction of biochemical methane potential (BMP) using different statistical models, Waste Manag. 48 (2016) 492. doi: https://doi.org/10.1016/j.wasman.2015.10.021

24. Jiang, Y., McAdam, E., Zhang, Y., Heaven, S., Banks, Ch., Longhurst, P., Ammonia inhibition and toxicity in anaerobic digestion: A critical review, J. Water Process Eng. 32 (2019) 100899. doi: https://doi.org/10.1016/j.jwpe.2019.100899

25. Sung, S., Liu, T., Ammonia inhibition on thermophilic anaerobic digestion, Chemosphere 53 (2003) 43. doi: https://doi.org/10.1016/S0045-6535(03)00434-X

26. Sun, Z. Y., Yamaji, S., Cheng, Q. S., Yang, L., Tang, Y. Q., $K i d a, K$., Simultaneous decrease in ammonia and hydrogen sulfide inhibition during the thermophilic anaerobic digestion of protein-rich stillage by biogas recirculation and air supply at $60{ }^{\circ} \mathrm{C}$, Process Biochem. 49 (2014) 2214. doi: https://doi.org/10.1016/j.procbio.2014.09.006 